\title{
The Relationship of Entrepreneurship Education and Entrepreneurial Intentions of University Students: The Mediating Effect of Attitudinal Factors
}

\author{
* Muhammad Sadiq, Lecturer \\ ** Dr. Riffat-un-Nisa Awan, Associate Professor (Corresponding Author) \\ *** Ghazanfar Ali, Lecturer
}

\begin{abstract}

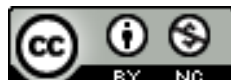

The study intended to examine the effect of entrepreneurship education on entrepreneurial intentions of students studying business education in different universities. More over the mediating effect of attitudinal factors on the relationship of intended variables was also explored. Six hundred graduate students were surveyed through a questionnaire from three public universities. The findings displayed that entrepreneurship education was significantly affecting entrepreneurial intentions of the students. Attitudinal factors have a strong mediation for entrepreneurship education and entrepreneurial intentions of higher education students. It can be concluded that entrepreneurial curricula and instruction along with attitudinal factors can add significantly to advance entrepreneurial intentions of students. It is suggested that the students of higher education, may be exposed towards entrepreneurship knowledge through regular instructional process, seminars and workshops to enhance their entrepreneurial capacities.
\end{abstract}

Keywords: Attitudinal Factors, Entrepreneurship Education, Entrepreneurial Intentions, University Students

\section{Introduction}

Menaces of poverty and unemployment in youth have become a great concern in underdeveloped countries like Pakistan. Number of unemployed graduates from higher education institutions is increasing day by day which is an inordinate worry for the policy makers. Such circumstances demand for entrepreneurship which plays a critical role in the national development. It is a kind of employment where one individual participates in social and economic activities as well as opens doors for others to take part in similar activities. According to Ragayah and Smith (2005) entrepreneurship is being considered a reasonable solution to corporate downsizing which has resulted in increased unemployment among the graduates.

Entrepreneurship intensions (EI) may be inculcated in students through entrepreneurial education (EE) by imparting knowledge, skills and attitudes which are helpful in establishing a business enterprise. Entrepreneurship education is an instructional program that uses specific teaching strategies and techniques in a conducive environment provided by universities to develop entrepreneurial intens ions and competence among students. (Cornelius, Landström, \& Persson, 2006). Gerba (2012) asserted that entrepreneurship training is a conscious strive driven by the people to expand the learning and aptitudes about business enterprise. It may be portrayed as a piece of new and present day business (Eisenberg \& Miller, 1987). Each student is assumed as a craftsman and the ideas, subsequently, are the workmanship.

Entrepreneurial intention is the propensity towards creating new business and enterprise. It is a self-conceived belief of a person who consciously plans to start a new enterprise at a certain point of time. Entrepreneurial intentions have been explored from different angles all over the world by different researchers including Asia (Dahalan, Jaafar, \& Rosdi, 2015; Zain, Akram, \& Ghani, 2010; Zarafshani \& Rajabi, 2011) Europe (Kristiansen \& Indarti, 2004; Liñán \& Chen, 2009; Turker \& Sonmez Selçuk, 2009), and Australia (Collins, 1998). Further, evidences in the literature depict that entrepreneurial intentions are determined by various demographic factors such as age, gender, education and working experience (Kristiansen \& Indarti, 2004; Schwarz, Wdowiak, Almer-Jarz, \& Breitenecker, 2009; Shinnar, Giacomin, \& Janssen, 2012).

\footnotetext{
* Govt. Institute of Commerce Sahiwal, Pakistan Email: msadiqhussain99@gmail.com

** Department of Education, University of Sargodha Email: riffarukh@ gmail.com

*** Department of Education, University of Sargodha Email: ghazanfaraliuos@ gmail.com
} 
Previous researches documented various factors including attitude which might impact entrepreneurial intentions. Geissler, Jahn, Loebel, and Zanger (2011) have mentioned numerous studies that provide evidence of the significance of entrepreneurial attitude as strong predictor of entrepreneurial intentions. Research on attitudinal factors and entrepreneurial intentions includes attitude toward change and money (Schwarz et al., 2009), personality traits and social intentions (Engle et al., 2010; Nga \& Shamuganathan, 2010), attitude toward new business venture (Liñán \& Chen, 2009), self-efficacy and need for achievement (Dahalan et al., 2015; Dahalan, Rosdi, \& Jaafar, 2011; Rachmawan, Lizar, \& Mangundjaya, 2015; Zhao, Seibert, \& Hills, 2005).

Entrepreneurship education is positively associated with entrepreneurial intentions as it assists the students to acquire new business prospects for starting a new business venture in a competitive environment (Davidsson \& Honig, 2003). The attitudinal factors encompass desirability, competitiveness, and opportunity alertness. Desirability is the amount of attraction a person feels towards a given intention as an entrepreneur. The individuals who acquire entrepreneurial education have more desirability and more knowledge about resource provisions and difficulties related with business (Fayolle, 2005). Past investigations have demonstrated that the individuals who proclaimed positive encounters in an entrepreneurial course had larger amounts of desirability and enthusiasm for business proprietorship than those with negative encounters (Souitaris, Zerbinati, \& Al-Laham, 2007; Zhao et al., 2005). The desires and dispositions towards turning into a business person have been appeared to be reliable indicators of entrepreneurial intentions (Davidsson, 1995).

Competitiveness is an ability to provide services and products efficiently and effectively than the relevant competitors. Competitiveness relates to the ability and readiness to win against the competitors. An ideal mentality towards competitiveness is seen as a factor affecting entrepreneurial tendency (Autio, Keeley, Klofsten, \& Ulfstedt, 1997). Opportunity a lertness refers to the capacity to recognize and exploit opportunity when it emerges. Entrepreneurial opportunities are basically the situations when new services, products, and raw materials can be sold and introduced at a better price than their cost (Shane \& Venkataraman, 2000). The capacity of opportunity alertness in an individual is his initiative towards setting up and starting a new business enterprise. Through this behavior the students weigh the entrepreneurial career path sturdier and they are more interested to start a new enterprise (Franke \& Lüthje, 2004).

It is a worldwide issue and a big concern from employers that university undergraduate programs have failed to provide graduates with the essential skills for their careers and professions (DeLa Harpe, Radloff, \& Wyber, 2000). Higher education institutions are producing graduates who have no demand in the job markets. Moreover the job opportunities are very few and far between. Unemployed graduates have become a major national problem. These circumstances demand for more emphasis on entrepreneurial education and development of entrepreneurial attitudes and intentions in graduates. Thus the present study proposes to determine whether the entrepreneurship education and attitudinal factors had an effect on entrepreneurial intentions of university students. Moreover, the mediating role of attitudinal factors like desirability, opportunity a lertness, and competitiveness was also studied in terms of their impact on the association of entrepreneurial education and entrepreneurial intentions of university students.

\begin{tabular}{|c|c|c|}
\hline \multirow[t]{2}{*}{ Inde pendent Variable } & Me diating Variable & \multirow[t]{2}{*}{ Dependent Variable } \\
\hline & $\begin{array}{l}\text { Attitudinal Factors } \\
\text { - Desirability } \\
\text { - Opportunity Alertness } \\
\text { - Competiti veness }\end{array}$ & \\
\hline \multicolumn{3}{|l|}{ Entrepreneurship } \\
\hline & & Entrepreneurial \\
\hline \multirow{2}{*}{$\begin{array}{l}\text { - Curricula } \\
\text { - Teaching Methodology } \\
\text { - University Role }\end{array}$} & & \\
\hline & & \\
\hline
\end{tabular}


Figure 1: Conceptual framework

As shown in Figure 1 entrepreneurship education was the main independent (predictor) variable and entrepreneurial intention was dependent variable of this study. Desirability, opportunity alertness, and competitiveness were mediating variables in the conceptual framework as components of Attitude.

\section{Population and Sample of the Study}

All the students who were studying entrepreneurship as a subject in the discipline of business and commerce education in public sector universities of the Punjab were the population of the study. Out of this population a sample size of 600 students was selected from three universities i.e. University of the Punjab, University of Sargodha, and Bahauddin Zakariya University, Multan (200 from each university).

\section{De velopment and Validation of the Research Instrument}

A questionnaire was developed after extensive review of related literature and consulting existing scales. The questionnaire was consisted of 7 subscales and 52 items. First subscale (for Entrepreneurship Education) 'Curricula' consisted of 10 items, second subscale; 'Teaching Methodology' consisted of 10 items, third subscale; 'University Role' consisted of 10 items, fourth subscale; 'Opportunity Alertness' consisted of 4 items, fifth subscale; 'Competitiveness' consisted of 6 items, sixth subscale; 'Entrepreneurial Intention' consisted of 8 items and seventh subscale; 'Desirability' consisted of 4 items.

Pilot testing was done by administering the tool to the business (BBA-Hons 15 \& MBA 15) and commerce (B.Com-Hons 15 \& M.Com 15) students at university of Sargodha. These 60 students were not included in the sample. Internal consistency coefficient using Cronbach's alpha was computed. The values of Cronbach alpha for this research instrument ranged from 0.70 to 0.83 . Factor-wise reliability coefficients for each factor are given in table 1.

\section{Data Analys is}

The effects of the predictor variables were measured through the Multiple Regressions using IBM SPSS 22. The overall model fit along with the effects of each predictor was assessed using multivariate statistics.

\section{Table 1}

Mean and SD of construct variables

\begin{tabular}{lllll}
\hline SN & Construct & Mean & SD & Cronbach Alpha \\
\hline 1 & *EE Curricula & 4.77 & 1.06 & 0.82 \\
2 & EE Teaching methodology & 4.66 & 0.98 & 0.77 \\
3 & EE University role & 4.50 & 1.12 & 0.83 \\
4 & $* *$ AF Desirability & 4.98 & 1.19 & 0.72 \\
5 & AF Opportunity alertness & 4.71 & 1.22 & 0.70 \\
6 & AF Competitiveness & 4.88 & 1.10 & 0.74 \\
7 & Entrepreneurial intentions & 4.92 & 1.02 & 0.75 \\
\hline
\end{tabular}

*EE stands for Entrepreneurship Education

**AF stands for Attitudinal Factor

Table 1 shows the curricula scores as $(\mathrm{M}=4.77 \mathrm{SD}=1.06)$, teaching methodology scores as $(\mathrm{M}=4.66 \mathrm{SD}=0.98)$, university role scores as $(\mathrm{M}=4.50, \mathrm{SD}=1.12)$, desirability scores as $(\mathrm{m}=4.98$, $\mathrm{SD}=1.19)$, opportunity a lertness scores as $(\mathrm{M}=4.71, \mathrm{SD}=1.22)$, competitiveness scores as $(\mathrm{M}=4.88$, $\mathrm{SD}=1.10)$, and entrepreneurial intentions scores as $(\mathrm{M}=4.92, \mathrm{SD}=1.02)$. Cronbach alpha reliability coefficients ranged from 0.070 to 0.83 which indicates that tools were highly reliable.

\section{Table 2}

The effect of entrepreneurial curricula, teaching methodology, and university role on desirability of higher education students

\begin{tabular}{llllll}
\hline Variables & \multicolumn{1}{c}{$\mathrm{B}$} & \multicolumn{1}{c}{ Std. Error } & $\beta$ & $t$ & Sig. \\
\hline (Constant) & 1.695 & .230 & & 7.356 & .000 \\
Curricula & .248 & .047 & .221 & 5.239 & .000 \\
Methodology & .428 & .056 & .353 & 7.605 & .000 \\
University Role $^{2}$ & .025 & .045 & .023 & .550 & .582 \\
Adjusted R & .268 & & & & \\
$F$ & $74.077(\mathrm{p}=.000)$ & & & \\
\hline
\end{tabular}

Predictors: (Constant), Curricula, Teaching methodology, University role

a. Dependent Variable: Entrepreneurial desirability 
The above tables show that a multiple linear regression was calculated to predict students' entrepreneurial desirability based on their entrepreneurship education curricula, teaching methodology, and university role. A significant regression equation was found $(F(3,596)=74.077, \mathrm{p}$ $<.000$, Adjusted $\mathrm{R}^{2}=.268$ ) significant. It was found that curricula $\beta=.221, t(596)=5.239, p<.000$, and teaching methodology $\beta=.353, t(596)=7.605, p<.000$, significantly predicted while university role $\beta=.023, t(596)=.550, \mathrm{p}<.582$ did not significantly predict entrepreneurial desirability of the students. The results indicated that curricula and teaching methodology were significantly and positively affecting the entrepreneurial desirability of higher education students whereas this was not the case for university role.

Table 3

The effect of entrepreneurial curricula, teaching methodology, and university role on opportunity alertness of higher education students

\begin{tabular}{llllll}
\hline Variables & \multicolumn{1}{c}{$\mathrm{B}$} & \multicolumn{1}{c}{ Std. Error } & $\beta$ & $t$ & Sig. \\
\hline (Constant) & 1.379 & .229 & -.038 & & \\
Curricula & -.044 & .047 & .364 & -.937 & .349 \\
Methodology & .452 & .056 & .294 & 7.096 & .000 \\
University Role & .319 & .044 & & 7.201 & .000 \\
Adjusted R & .314 & & & \\
$F$ & $91.039(\mathrm{p}=.000)$ & & & \\
\hline
\end{tabular}

Predictors: (Constant), Curricula, Teaching methodology, University role

a. Dependent Variable: Entrepreneurial opportunity alertness

The above tables show that a significant regression equation was found $(F(3,596)=91.039, \mathrm{p}$ $<.000)$. It was found that students' entrepreneurial opportunity alertness is equal to $1.379-.044$ (curricula) +0.452 (teaching methodology) +0.319 (university role). The results indicate that the teaching methodology $\beta=.364, t(596)=8.096, p<.000$, and university role $\beta=.294, t(596)=$ $7.201, p<.000$, had significant effect on entrepreneurial opportunity alertness whereas curricula failed to effect the entrepreneurial opportunity alertness of higher education students.

Table 4

The effect of entrepreneurship education curricula, teaching methodology, and university role on competitiveness of higher education students

\begin{tabular}{llllll}
\hline Variables & \multicolumn{1}{c}{$\mathrm{B}$} & \multicolumn{1}{c}{ Std. Error } & Beta & $t$ & Sig. \\
\hline (Constant) & 1.382 & .201 & & 6.888 & .000 \\
Curricula & .154 & .041 & .148 & 3.735 & .000 \\
Methodology & .480 & .049 & .427 & 9.801 & .000 \\
University Role $^{\text {Adjusted R }}{ }^{2}$ & .117 & .039 & .119 & 3.015 & .003 \\
$F$ & .354 & & & & \\
\hline
\end{tabular}

Predictors: (Constant), Curricula, Teaching methodology, University role

a. Dependent Variable: Entrepreneurial competitiveness

The above tables show that a multiple linear regression was calculated to analyze students' entrepreneurial competitiveness based on their entrepreneurial curricula, teaching methodology, and university role. A significant regression equation was found $(F(3,596)=110.285, \mathrm{p}<.000)$, with an $\mathrm{R}^{2}$ of .354 . It was found that students' entrepreneurial competitiveness is equal to $1.382+0.154$ (curricula) +0.480 (teaching methodology) +0.117 (university role). The results indicate that entrepreneurial curricula $(\beta=.148, t(596)=3.735, p<.000)$, teaching methodology $(\beta=.427, t(596)$ $=9.801, p<.000)$, and university role $(\beta=.119, t(596)=3.015, p<.003)$ had significant positive effect on the entrepreneurial competitiveness of higher education students.

\section{Table 5}

The effect of attitudinal factors desirability, opportunity alertness, and competitiveness on entrepreneurial intention of higher education students

\begin{tabular}{lccccc}
\hline Variables & B & Std. Error & $\beta$ & $t$ & Sig. \\
\hline (Constant) & 1.584 & .161 & & 9.836 & .000 \\
Desirability & .216 & .034 & .253 & 6.268 & .000 \\
Opportunity & .154 & .031 & .185 & 4.941 & .000 \\
alertness & .313 & .039 & .339 & 8.124 & .000 \\
Competitiveness & .425 & & & & \\
Adjusted R & & & & & \\
\hline
\end{tabular}


\begin{tabular}{ll}
\hline \hline$F$ & $148.7159(\mathrm{p}=.000)$ \\
\hline a. & Predictors: (Constant), Desirability, opportunity alertness, competitiveness \\
b. Dependent Variable: Entrepreneurial intentions \\
$\quad$ The above tables show that a multiple linear regression was calculated to analyze students'
\end{tabular} entrepreneurial intentions based on their attitudinal factors desirability, opportunity alertness, and competitiveness. It was found that students' entrepreneurial intentions $(F(3,596)=148.715, \mathrm{p}<$ $.000)$ are equal to $1.584+0.216$ (desirability) +0.154 (opportunity alertness) +0.313 (competitiveness). The results indicate that the attitudinal factors i.e. desirability $(\beta=.253, t(596)=$ $6.268, p<.000)$, opportunity alertness $(\beta=.185, t(596)=4.941, p<.000)$, and competitiveness $(\beta=$ $.339, t(596)=8.124, p<.000$ ) had significant effect on entrepreneurial intentions of higher education students.

\section{Mediation Analys is}

The following figure gives the details of mediation analysis.

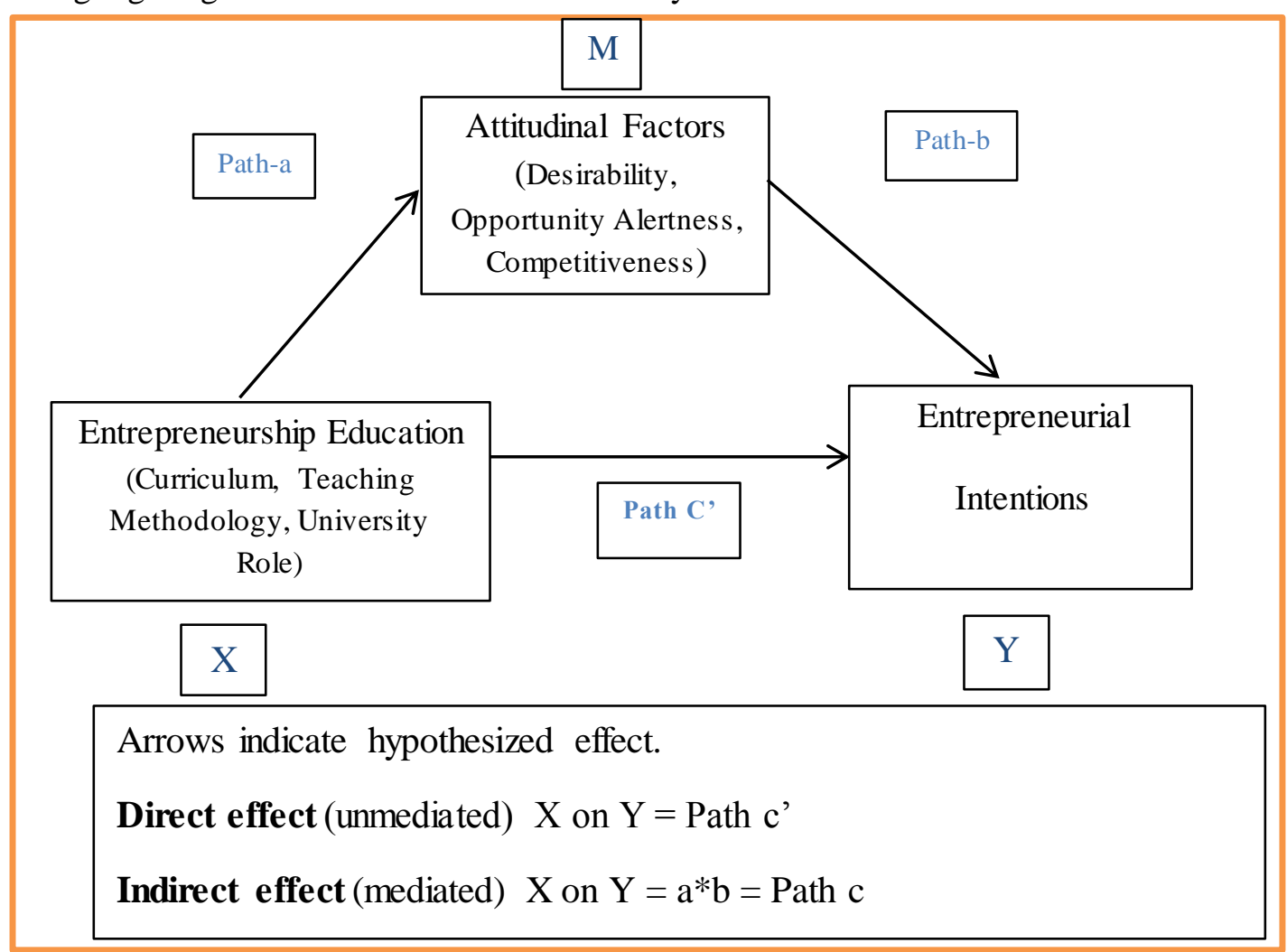

Figure: Conceptual framework of hypothesized mediation analysis

Table 6

Direct and Indirect effects of desirability, entrepreneurship education and entrepreneurial intentions

\begin{tabular}{lllll}
\hline Direct Effects * & Effects & SE & $t$ & $\mathrm{p}$ \\
\hline Curricula & .271 & .035 & 7.833 & .000 \\
Teaching Methodology & .440 & .037 & 12.082 & .000 \\
University Role & .368 & .029 & 12.776 & .000 \\
\hline Indirect Effects** & Effect & Boot SE & BootLLCI & BootULCI \\
\hline Curricula & .175 & .023 & .134 & .224 \\
Teaching Methodology & .173 & .026 & .126 & .227 \\
University Role & .117 & .021 & .082 & .161 \\
\hline
\end{tabular}

*Path c'= Entrepreneurship Education $\longrightarrow$ Entrepreneurial Intentions

**Path $\mathbf{c}, \mathbf{a}^{*} \mathbf{b}=$ Entrepreneurship Education $\longrightarrow$ Desirability $\longrightarrow$ Entrepreneurial intentions

The calculated direct effect of entrepreneurial curricula on entrepreneurial intentions is .271

$(27.09 \%)$ and the indirect effect or mediated effect is $(\beta=.175, \mathrm{p}<0.05)$. Table also shows indirect effect is also significant and LLCI/ULCI $(.1339, .2236)$ are different from zero. So, mediation suggested by model is partial mediation. The direct effect of teaching methodology on entrepreneurial intentions is $.440(44.02 \%)$ and the indirect effect or mediated effect is $(\beta=.1727, p<0.05)$. As table 
shows that LLCI/ULCI $(.1257, .2265)$ are different from zero, so mediation suggested by model is partial mediation. The calculated direct effect of university role on entrepreneurial intentions is $36.77 \%$ and the indirect effect is $(\beta=.1164, \mathrm{p}<0.05)$. Above table also shows that LLCI/ULCI $(.082$, $.161)$ are different from zero. So, model suggested partial mediation.

Table 7

Direct and Indirect effects of Opportunity Alertness, entrepreneurship education and entrepreneurial intentions

\begin{tabular}{lllll}
\hline Direct Effects $*$ & Effects & SE & $t$ & $\mathrm{p}$ \\
\hline Curricula & .344 & .033 & 10.412 & .000 \\
Teaching Methodology & .484 & .038 & 12.624 & .000 \\
University Role & .358 & .034 & 10.524 & .000 \\
\hline Indirect Effects** & Effect & Boot SE & BootLLCI & BootULCI \\
\hline Curricula & .102 & .018 & .0691 & .142 \\
Teaching Methodology & .129 & .025 & .0848 & .183 \\
University Role & .127 & .023 & .0861 & .176 \\
\hline
\end{tabular}

*Path c'= Entrepreneurship Education $\longrightarrow$ Entrepreneurial Intentions

**Path $\mathbf{c}, \mathbf{a}^{*} \mathbf{b}=$ Entrepreneurship Education $\longrightarrow$ Opportunity Alertness $\rightarrow$ Entrepreneurial intentions

The calculated direct effect of entrepreneurial curricula on entrepreneurial intentions is $34.40 \%$ and the indirect effect or mediated effect is $(\beta=.102, \mathrm{p}<0.05)$. The calculated direct effect of teaching methodology on entrepreneurial intentions is $(48.35 \%)$ and the mediated effect is $(\beta=.1294$, $\mathrm{p}<0.05)$ explaining that teaching methodology through opportunity alertness effect $(12.94 \%)$ entrepreneurial intentions. The direct effect of university role on entrepreneurial intentions is $35.72 \%$ and the indirect effect or mediated effect is $(\beta=.1269, \mathrm{p}<0.05)$ significant explaining that university role through opportunity a lertness effects $(12.69 \%)$ entrepreneurial intentions. Mediation suggested by model for all three mediators is partial mediation.

Table 8

Direct and Indirect effects of Competitiveness, entrepreneurship education and entrepreneurial intentions

\begin{tabular}{lllll}
\hline Direct Effects $*$ & Effects & SE & $t$ & P \\
\hline Curricula & .247 & .034 & 7.352 & .000 \\
Teaching Methodology & .389 & .039 & 10.054 & .000 \\
University Role & .318 & .030 & 10.580 & .000 \\
\hline Indirect Effects** & Effect & Boot SE & BootLLCI & BootULCI \\
\hline Curricula & .198 & .024 & .155 & .249 \\
Teaching Methodology & .224 & .031 & .168 & .291 \\
University Role & .166 & .023 & .127 & .217 \\
\hline
\end{tabular}

*Path c'= Entrepreneurship Education $\longrightarrow$ Entrepreneurial Intentions

**Path $\mathbf{c}, \mathbf{a}$ *b $\mathbf{b}=$ Entrepreneurship Education $\longrightarrow$ Competitiveness $\longrightarrow$ Entrepreneurial intentions

The calculated direct effect of curricula (.247, p .000) on entrepreneurial intentions is $24.73 \%$ and the indirect effect or mediated effect is $(b=.1982, p<0.05)$ telling that entrepreneurial curricula through competitiveness effects $(19.82 \%)$ entrepreneurial intentions. The calculated direct effect of teaching methodology on entrepreneurial intentions is $38.86 \%$ and the indirect effect or mediated effect is $(b=.2242, p<0.05)$ and explain that teaching methodology through competitiveness effects $(22.42 \%)$ entrepreneurial intentions. The calculated direct effect of university role on entrepreneurial intentions is $31.79 \%$ and the indirect effect or mediated effect is $(b=.1662, p<0.05)$ explaining that university role through competitiveness effects $(16.62 \%)$ entrepreneurial intentions. The mediation suggested by model in all three cases is partial mediation.

\section{Discussion}

The present research was designed to find the effect of entrepreneurial education on entrepreneurial intentions of higher education students and the results explained significant effect in this regard. These results were similar to many researches done previously (Bae, Qian, Miao, \& Fiet, 2014; Lanero \& Vazquez, 2015; Maes, Leroy, \& Sels, 2014; Vidal-Suñé \& López-Panisello, 2013)

The research also aimed at finding the mediating effect of attitudinal factors (desirability, opportunity alertness, and competitiveness) on the relationship between EE curricula, teaching methodology, and university role and entrepreneurial intentions. The results indicated that the mediating effect of attitudinal factors was significant for EE and EI of higher education students at the 
Punjab. The results were similar to many researches like Maes et al. (2014), Wurthmann (2014) Solesvik (2013) Byabashaija and Katono (2011) Florin, Karri, and Rossiter (2007) and Lanero and Vazquez (2015). This is true that an individual's attitudinal dynamics can place that person in a better situation to be an entrepreneur (Krueger Jr, Reilly, \& Carsrud, 2000). Florin et al. (2007) assert that for making students entrepreneurs and for developing and fostering entrepreneurial drive in them it is not enough to just teach them skills, but rather to develop initiatives throughout the business program. The results of this research revealed that students' experience of entrepreneurship education has a significant effect on attitudinal factors (desirability, opportunity alertness, and competitiveness) and entrepreneurial intentions. The result also revealed the presence of attitudinal factors in the interplay of EE and EI of higher education students is highly effective. These findings coincide with another research where EE did not influence EI directly, but had an indirect effect through attitudes towards entrepreneurship (Ndofirepi \& Rambe, 2017). The results validate the importance of attitude sources as a channel in improving the association between EE and EI of higher education students like some other factors such as individual differences and cultural context (Bae et al., 2014).

\section{Conclusion}

This study concludes that EE (curricula, teaching methodology, and university role) and attitudinal factors like desirability, opportunity alertness, and competitiveness play a major and substantial role in fostering entrepreneurial intentions. Entrepreneurial education is felt essential condition but still not enough to enhance entrepreneurial inclinations without combing with attitudinal factors like desirability, opportunity recognition and exploitation, and competitiveness.

It is recommended that with declining training opportunities, universities have a substantial responsibility to teach both contents and required business planning and organizing skills to the students. It implies that when the desire, opportunities, and competitiveness are being reflected by the students, teachers may use pedagogical approaches which enable students to work on novel and innovative business projects. Teachers and instructors are obliged to increase entrepreneurial intentions of the students by assigning them tasks and projects which clarify the entrepreneurial process and construct the attitude that leads them to be entrepreneurial in the future.

It is suggested that the students of higher education, may be exposed towards entrepreneurship knowledge through regular instructional process, seminars and workshops to enhance their entrepreneurial capacities. It will improve the entrepreneurial information process, entrepreneurial skills and entrepreneurial awareness.

\section{References}

Autio, E., Keeley, R. H., Klofsten, M., \& Ulfstedt, T. (1997). Entrepreneurial intent among students: testing an intent model in Asia, Scandinavia and USA.

Bae, T. J., Qian, S., Miao, C., \& Fiet, J. O. (2014). The relationship between entrepreneurship education and entrepreneurial intentions: A meta-analytic review. Entrepreneurship Theory and Practice, 38(2), 217-254.

Byabashaija, W., \& Katono, I. (2011). The impact of college entrepreneurial education on entrepreneurial attitudes and intention to start a business in Uganda. Journal of Developmental Entrepreneurship, 16(01), 127-144.

Collins, J. (1998). Cosmopolitan capitalism: ethnicity, gender and Australian entrepreneurs.

Cornelius, B., Landström, H., \& Persson, O. (2006). Entrepreneurial studies: The dynamic research front of a developing social science. Entrepreneurship Theory and Practice, 30(3), 375-398.

Dahalan, N., Jaafar, M., \& Rosdi, S. A. M. (2015). Attitude and entrepreneurial intention among rural community: the mediating role of entrepreneurial opportunity recognition. Paper presented at the SHS Web of Conferences.

Dahalan, N., Rosdi, S. A. M., \& Jaafar, M. (2011). Factors Influencing Entrepreneurial Intention: A Proposed Framework. Paper presented at the Proceedings of 2nd Regional Conference on Tourism Research.

Davidsson, P. (1995). Determinants of entrepreneurial intentions.Unpublished manuscript, Jönköping International Business School (JIBS), Swedon. https://pdfs.semanticscholar.org/8690/ 66b0890c6d097443bf0f6f3a0ca983bfa12b.pdf

Davidsson, P., \& Honig, B. (2003). The role of social and human capital among nascent entrepreneurs. Journal of Business venturing, 18(3), 301-331. 
DeLa Harpe, B., Radloff, A., \& Wyber, J. (2000). Quality and generic (professional) skills. Quality in Higher Education, 6(3), 231-243.

Eisenberg, N., \& Miller, P. A. (1987). The relation of empathy to prosocial and related behaviors. Psychological bulletin, 101(1), 91.

Engle, R. L., Dimitriadi, N., Gavidia, J. V., Schlaegel, C., Delanoe, S., Alvarado, I., . . . Wolff, B. (2010). Entrepreneurial intent: A twelve-country evaluation of Ajzen's model of planned behavior. International Journal of Entrepreneurial Behavior \& Research, 16(1), 35-57.

Fayolle, A. (2005). Evaluation of entrepreneurship education: behaviour performing or intention increasing? International Journal of Entrepreneurship and Small Business, 2(1), 89-98.

Florin, J., Karri, R., \& Rossiter, N. (2007). Fostering entrepreneurial drive in bus iness education: An attitudinal approach. Journal of management education, 31(1), 17-42.

Franke, N., \& Lüthje, C. (2004). Entrepreneurial intentions of business students-A benchmarking study. International Journal of Innovation and Technology Management, 1 (03), 269-288.

Geissler, M., Jahn, S., Loebel, H., \& Zanger, C. (2011). From business opportunity to action: What lies in between? Paper presented at the ICSB World Conference Proceedings.

Gerba, D. T. (2012). The context of entrepreneurship education in Ethiopian universities. Management Research Review, 35(3/4), 225-244.

Kristiansen, S., \& Indarti, N. (2004). Entrepreneurial intention among Indonesian and Norwegian students. Journal of Enterprising Culture, $12(01), 55-78$.

Krueger Jr, N. F., Reilly, M. D., \& Carsrud, A. L. (2000). Competing models of entrepreneurial intentions. Journal of business venturing, 15(5-6), 411-432.

Lanero, A., \& Vazquez, J.-L. (2015). A social cognitive model of entrepreneurial intentions in university students. Anales de Psicología, 31(1), 243.

Liñán, F., \& Chen, Y. W. (2009). Development and Cross-Cultural application of a specific instrument to measure entrepreneurial intentions. Entrepreneurship Theory and Practice, 33(3), 593-617.

Maes, J., Leroy, H., \& Sels, L. (2014). Gender differences in entrepreneurial intentions: A TPB multigroup analysis at factor and indicator level. European Management Journal, 32(5), 784-794.

Ndofirepi, T. M., \& Rambe, P. (2017). Entrepreneurship education and its impact on the entrepreneurship career intentions of vocational education students. Problems and Perspectives in Management, 15(1-1), 191-199.

Nga, J. K. H., \& Shamuganathan, G. (2010). The influence of personality traits and demographic factors on social entrepreneurship start up intentions. Journal of business ethics, 95(2), 259282.

Rachmawan, A., Lizar, A. A., \& Mangundjaya, W. L. (2015). The role of parent's influence and selfefficacy on entrepreneurial intention. The Journal of Developing Areas, 49(3), 417-430.

Ragayah, M. Z., \& Smith, W. (2005). Malaysia: Unemployment in the midst of full employment. In J. Benson \& Y. Zhu (Eds.), Unemployment in Asia NY: Routledge.

Schwarz, E. J., Wdowiak, M. A., Almer-Jarz, D. A., \& Breitenecker, R. J. (2009). The effects of attitudes and perceived environment conditions on students' entrepreneurial intent: An Austrian perspective. Education + Training, 51(4), 272-291.

Shane, S., \& Venkataraman, S. (2000). The promise of entrepreneurship as a field of research. Academy of management review, 25(1), 217-226.

Shinnar, R. S., Giacomin, O., \& Janssen, F. (2012). Entrepreneurial perceptions and intentions: The role of gender and culture. Entrepreneurship Theory and Practice, 36(3), 465-493.

Solesvik, M. Z. (2013). Entrepreneurial motivations and intentions: investigating the role of education major. Education+ Training, 55(3), 253-271.

Souitaris, V., Zerbinati, S., \& Al-Laham, A. (2007). Do entrepreneurship programmes raise entrepreneurial intention of science and engineering students? The effect of learning, inspiration and resources. Journal of Business venturing, 22(4), 566-591.

Turker, D., \& Sonmez Selçuk, S. (2009). Which factors affect entrepreneurial intention of university students? Journal of European industrial training, 33(2), 142-159.

Vidal-Suñé, A., \& López-Panisello, M.-B. (2013). Institutional and economic determinants of the perception of opportunities and entrepreneurial intention. Investigaciones Regionales-Journal of Regional Research(26), 75-96. 
Wurthmann, K. (2014). Business students' attitudes toward innovation and intentions to start their own businesses. International Entrepreneurship and Management Journal, 10(4), 691-711.

Zain, Z. M., Akram, A. M., \& Ghani, E. K. (2010). Entrepreneurship intention among Malaysian business students. Canadian social science, 6(3), 34-44.

Zarafshani, K., \& Rajabi, S. (2011). Effects of personality traits on entrepreneurial intentions: An empirical study in Iran. International Journal of Management, 28(3), 630.

Zhao, H., Seibert, S. E., \& Hills, G. E. (2005). The mediating role of self-efficacy in the development of entrepreneurial intentions. Journal of applied psychology, 90(6), 1265. 